The BDJ News section accepts items that include general news, latest research and diary events that interest our readers. Press releases or articles may be edited, and should include a colour photograph if possible. Please direct your correspondence to the News Editor, Arveen Bajaj at the BDJ, 64 Wimpole Street WIG 8YS or by e-mail to bdj@bda.org

\section{Meeting notice}

Enclosed in this issue of the BDJ is a letter giving notice of an Extraordinary General Meeting of Members of the British Dental Association. It will be held at 64 Wimpole Street, London W1G 8YS on Saturday 11 October 2003 at $10.00 \mathrm{am}$.

Further copies of the letter can be accessed on the BDA Website www.bda.org or obtained from Dan Berry on 02075634579.

\section{Fitness to practice panel appointed}

The GDC has appointed the members of the its new, independent Fitness to Practice Panel. The panel members will make up the committees which decide on dental professionals' fitness to practice.

In the past the committees which made decisions on dental professionals' fitness to practice were made up of GDC members. Membership of these committees will now be drawn from this independent pool of dental professionals and lay people called the Fitness to Practice Panel.

The appointment decisions were made on merit. Within the field of candidates judged to be 'appointable', regard was given to achieving a balance in terms of age, background and experience (both dental and lay), gender and ethnic origin.

The Appointments Committee found it had a strong field of very good quality candidates, sufficient to appoint to all 35 posts as well as to establish a Reserve List, from which to draw if positions fell vacant during the next 12 months.

All members will receive regular further training throughout their period of service in, for example, changes in the law, new procedures, the impact of appeal decisions, other areas as required and/or as identified by members themselves.

Additionally, particular training in the role of Panel Chair will be provided for current and prospective Chairs. There will also be an appraisal system.

\title{
Fun at the fayre
}

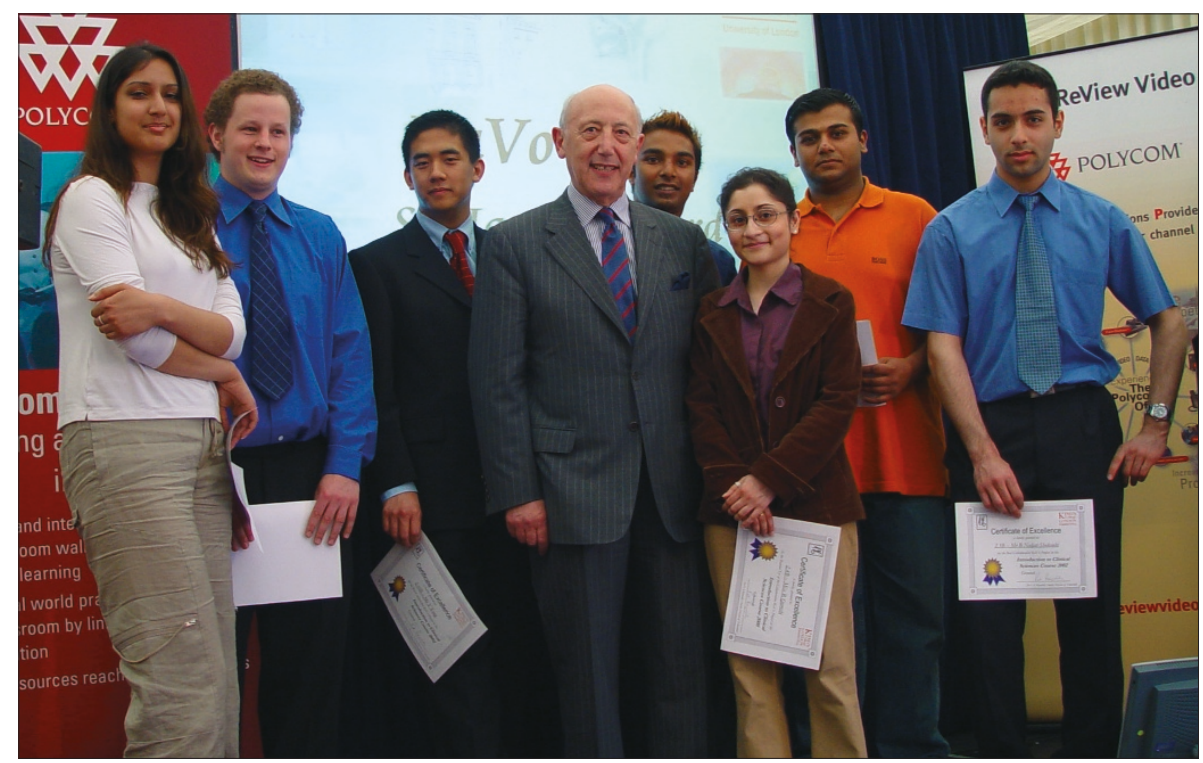

Year two dental students from GKT Dental School were awarded KaVo Prizes by Sir lan Gainsford (centre) for their collaborative projects designing the 'Dental Surgery of the 21st Century'. The presentation took place at the GKT Summer Fayre, Innovations in Education. Nairn Wilson, Dean and Head of the GKT Dental Institute invited over 30 exhibitors to demonstrate their expertise ranging from BBC Technology to webcasting at King's during a day of events and presentations. The aim of the day was to raise awareness of new dimensions in teaching and learning, and to highlight the ways that educational innovations can apply to both lecturer and student in higher education and Continuing Professional Development. Events included a multinational video-conference which crossed three continental time zones with links to centres in Australia, South Africa, the USA and to the Wooton Bridge Dental Practice in the Isle of Wight and also a real and virtual balloon race.

\section{Dental students drowning under debt}

Over a third of UK dental graduates are making career decisions influenced by the level of debt they have accrued at university according to a survey by the British Dental Association.

The findings have prompted concerns that areas within the dental profession, like community dental services which already struggle with recruitment and retention, will continue to suffer.

The BDA's survey found that debt among dental graduates continues to rise. Average figures are up 23 per cent on last year alone and, perhaps more alarmingly, the percentage of graduates with debts over $£ 30,000$ has more than tripled since 2001.

Concerns over debts are making a difference to undergraduate life for many dental students. One in five lived at home while studying, with almost two-thirds of these citing finances as the core reason.

The survey found that the average debt this year amongst final year students in 2003 was $£ 12,700$. On average, men have higher debts than women ( $£ 13,900$ versus $£ 11,600)$ and students aged 23 or 24 have higher debts than younger or older students ( $£ 13,300$ versus $£ 12,000$ for those aged $21-22$ and $£ 10,200$ for those aged 25-34).

To subsidise spending, 49 per cent of respondents had taken on a part-time job. The survey was distributed to the 13 UK dental schools in May 2003. 


\section{DIARY}

September 2003

Annual Meeting of the International Society for the Prevention of Tobacco Induced Diseases

Date: 29.09.03-01.10.03

Venue: Winnipeg, Canada

Contact: PTID-Society (Congress 2003)

Fax: + 1 (204) 789-3913

E-mail: ptidsociety@aol.com

The Faculty of General Dental Practitioners (UK) - Preservative Dentistry: Is less more? Date: 25.09 .03

Venue: Manchester Dental Education

Centre, Manchester

Tel: 01612756600

www.den.man.ac.uk

October 2003

The challenge of change

Date: 10.10 .03

Venue: New Connaught Rooms, London Contact: Brenda Grant, BDA Conference Desk

Tel: 02085427622

E-mail: bda@vistaevents.co.uk

May 2004

BDA National Annual Conference Date: 06.05.04 - 08-05.04

Contact: Events Office,

British Dental Association

Venue: Bouremouth International Centre

Tel: +44 (0) 2075634590

Fax: +44 (0) 2075634591

E-mail: events@bda.org

\section{Chernobyl children arrive for dental treatment}

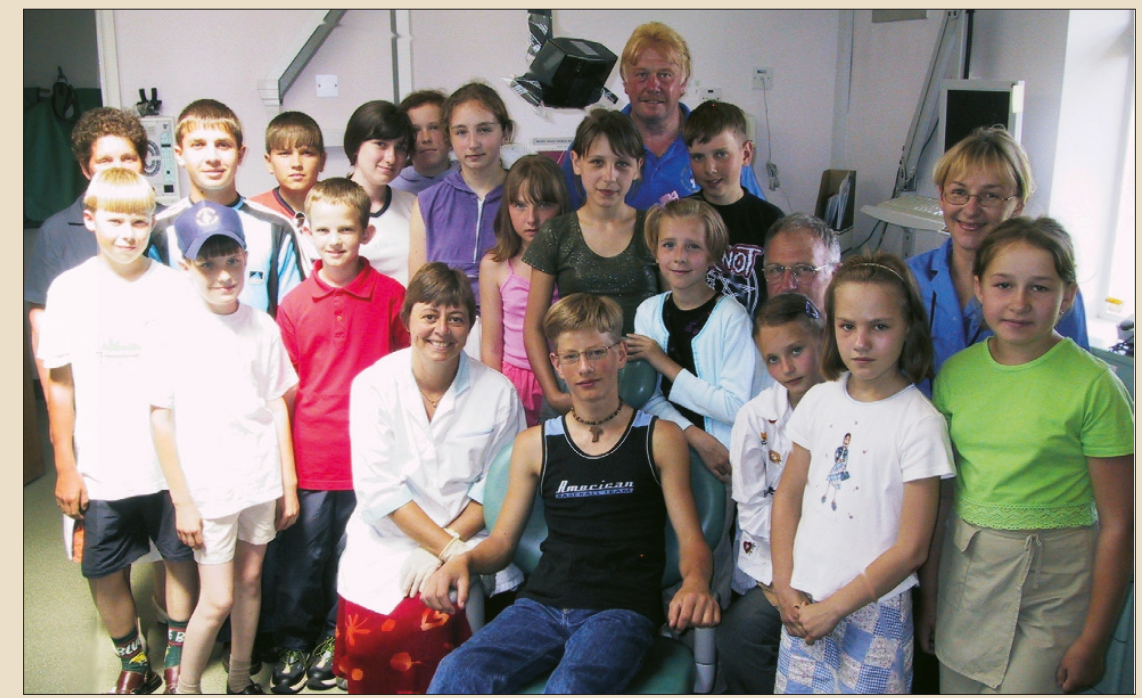

Chesterfield Primary Care Trust (PCT) has been playing host to a group of children from the radiation-affected country of Belarus. The children were given dental check-ups by the PCT's Community Dental Service at Saltergate Health Centre.

Many children from Belarus visit the United Kingdom each year, as a result of the work of Chernobyl Children Lifeline, a national charity that links with rural Belarussian communities. The charity gives the poorly children a chance to live in a 'clean' environment and eat uncontaminated foods for a month.

Children visiting north Derbyshire receive support from a variety of sectors in the community. For the past three years, dental care has been provided jointly by general dental practitioners and the Community Dental Service Children also receive other health care, including eye tests.

Belarus received 70 per cent of the radioactive fallout from the Chernobyl nuclear explosion in April 1986 and as a result, tens of thousands of children are now being born every year with thyroid cancer, bone cancer and leukaemia. Only five per cent of children in the Chernobyl region are left healthy.

To bring child victims of the Chernobyl disaster to the UK for recuperative breaks of one month costs £250, money which initially comes from the charity but is then continued by families who pay for children to return each year; over 21,000 have been to stay with host families since 1992. 


\section{Smiles all around}

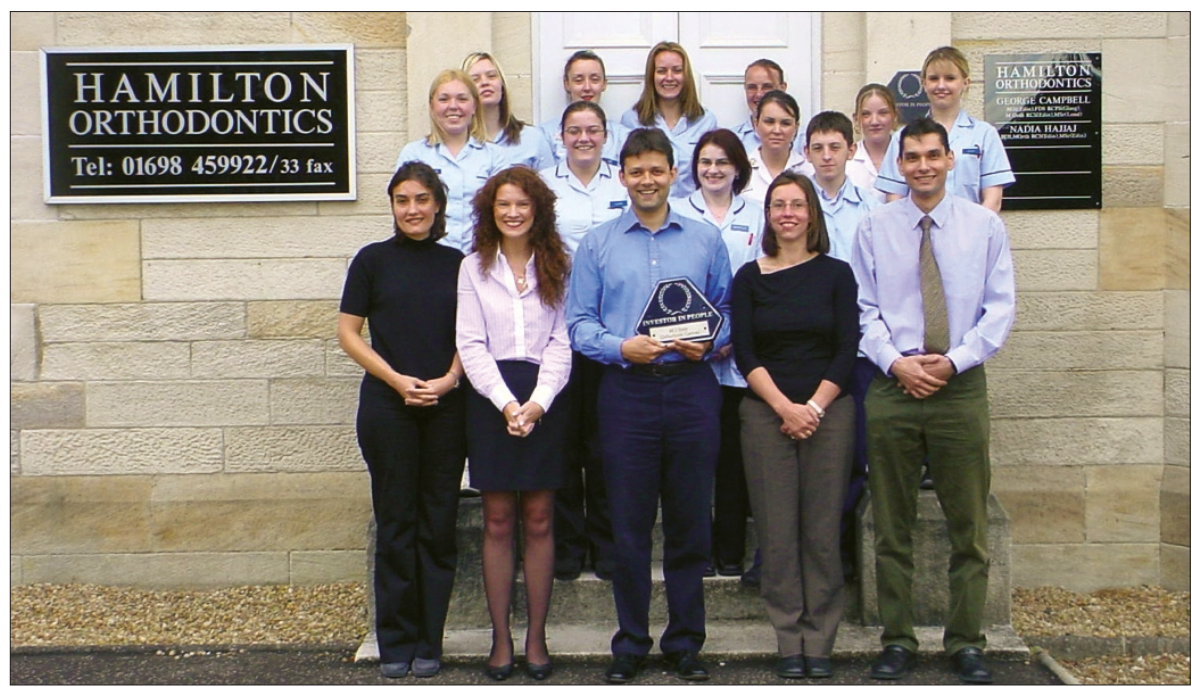

All 1 Smile Orthodontic Centre has been recognised as an Investor in People for their commitment to best practice in managing people towards business goals. The standard was achieved through a structured training and development programme, appraisal system, communication briefings and other initiatives which have created a learning environment with a happy and relaxed working atmosphere.

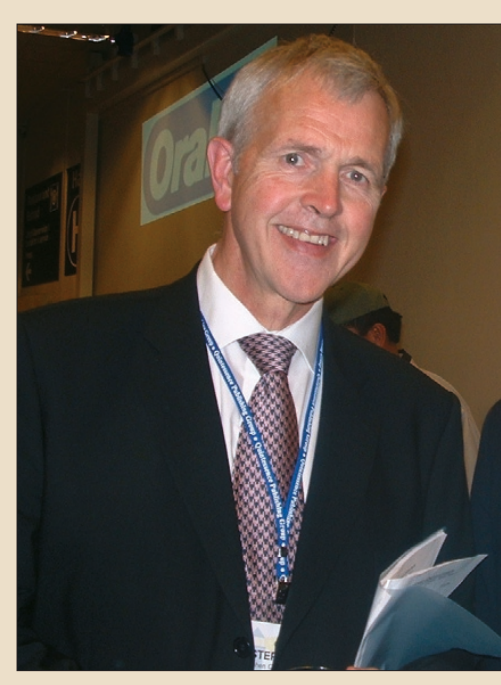

\section{New IADR president}

Professor Stephen Challacombe of the Guys Kings and St Thomas' Dental Institute (GKT) of Kings College London was inaugurated as the 82nd President of the International Association for Dental Research at the recent meeting of the IADR in Goteborg, Sweden.

He is only the third British president in the 82 years of the IADR following Martin Rushton in 1965, and Graham Embery in 2001. Professor Challacombe holds the Martin Rushton Chair in Oral Medicine at GKT, and has previously been President of the British Society for Dental Research, of the British Society for Oral Medicine and of the Metropolitan Branch of the BDA.

\section{High achievers}

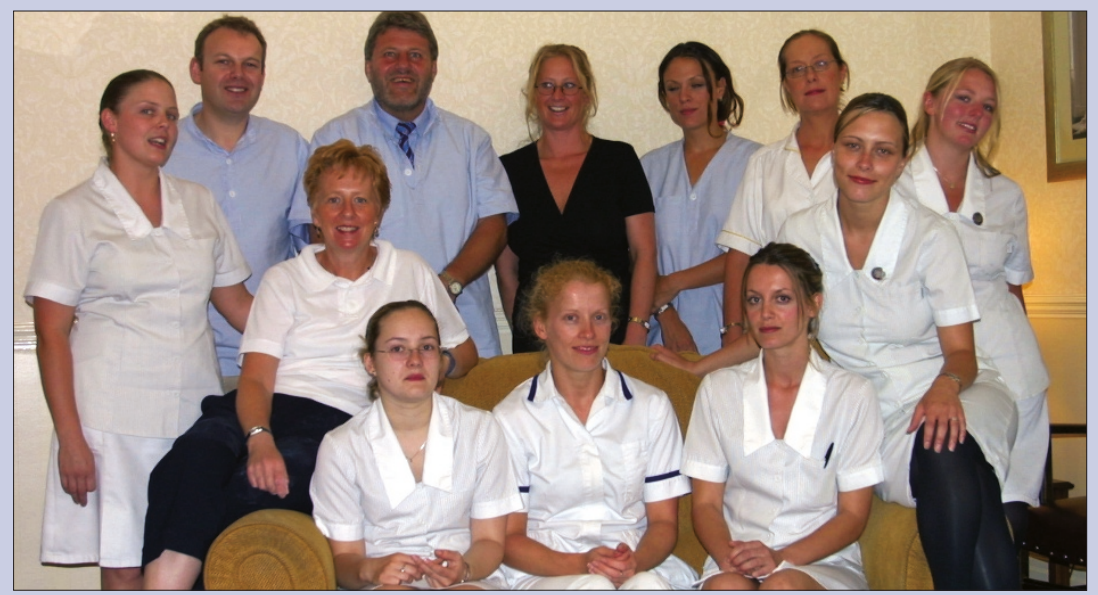

Leicester dental practice James Cooil and Associates are the latest practice to be recognised as an Investor in People. It has been pleased with the difference the achievement has made to improving good functioning of the practice as a whole. 